\title{
Anticancer Effects of Curcumin, Artemisinin, Genistein, and Resveratrol, and Vitamin C: Free Versus Liposomal Forms
}

\author{
Jerry T. Thornthwaite1 ${ }^{*}$, Hare R. Shah ${ }^{1}$, Spencer R. England ${ }^{1}$, Lee H. Roland ${ }^{1}$, Seth P. Thibado ${ }^{2}$, \\ Thomas K. Ballard ${ }^{3}$, Brandon T. Goodman ${ }^{1}$
}

${ }^{1}$ Cancer Research Institute of West Tennessee, Henderson, TN, USA

${ }^{2}$ Union University Department of Chemistry, Jackson, TN, USA

${ }^{3}$ University of Tennessee Department of Biochemistry, Knoxville, TN, USA

Email: *jtt@criwt.com

How to cite this paper: Thornthwaite, J.T., Shah, H.R., England, S.R., Roland, L.H., Thibado, S.P., Ballard, T.K. and Goodman, B.T. (2017) Anticancer Effects of Curcumin, Artemisinin, Genistein, and Resveratrol, and Vitamin C: Free Versus Liposomal Forms. Advances in Biological Chemistry, 7, 27-41.

https://doi.org/10.4236/abc.2017.71002

Received: December 24, 2016

Accepted: February 12, 2017

Published: February 15, 2017

Copyright $\odot 2017$ by authors and Scientific Research Publishing Inc. This work is licensed under the Creative Commons Attribution International License (CC BY 4.0).

http://creativecommons.org/licenses/by/4.0/

\begin{abstract}
Cancer prevention supplements, which also provide effective treatment with minimal side effects, are urgently needed. An accurate, fast assay system is described that reveals the ability of chemically defined products, such as curcumin, genistein, resveratrol, artemisinin, and vitamin C, to kill K562 Erythroleukemic cells in vitro. In addition, curcumin and vitamin $\mathrm{C}$ were encapsulated into fatty acid micelles named NutraNanoSpheres ${ }^{\mathrm{TM}}$ (NNS) using all natural products. A unique viability stain, which allows the rapid staining of dead cells by membrane penetration using Propidium Iodide, was used to measure the cell viability by flow cytometry. Cell death by alteration of the cell membranes could be seen within $30 \mathrm{~s}$ of exposure to curcumin. The other free components required $0.5-70 \mathrm{~h}$ to see maximum killing, suggesting a more metabolic and/or apoptotic route of cancer cell destruction. Vitamin C up to 1 $\times 10^{4} \mu \mathrm{mol} /$ well did not affect K562 cell viability. The vitamin C-NNS $(3.2 \mathrm{~nm}$ diameter-60 mg/50 $\mu \mathrm{L})$ showed an $\mathrm{LD}_{50}=133 \mu \mathrm{mol} /$ well $\pm 11 \mathrm{SD}(\mathrm{n}=4)$, which was over 75 times more potent than the free vitamin $\mathrm{C}$. The curcumin-NNS $(7.4 \mathrm{~nm}$ diameter- $25 \mathrm{mg} / 50 \mu \mathrm{L})$ resulted in an $\mathrm{LD}_{50}=41.3$ $\mu \mathrm{mol} /$ well $\pm 5.6 \mathrm{SD}(\mathrm{n}=8)$ and represented a 264 fold increase in activity to destroy the cancer cells. The clinical goal is to develop water-soluble mixtures of anti-cancer compounds in the NNS with their high bioavailability (>90\%) and without degradation in the stomach for preventing and curing cancer.
\end{abstract}

\section{Keywords}

Curcumin, Artemisinin, Cancer, Micelle, Natural 


\section{Introduction}

Cancer is one of the major causes of death worldwide, and minimal progress has been accomplished in reducing its morbidity [1]. Cancer is caused by one or a combination of at least three factors: unhealthy diet, genetic predisposition, and the environment. Estimates by the American Cancer Society are that over $90 \%$ of all cancers are caused by lifestyle and may take as long as 20 - 30 years to develop. Current estimates from the American Cancer Society and from the International Union Against Cancer indicate that 12 million cases of cancer were diagnosed last year, with 7 million deaths worldwide; these numbers are expected to double in 15 years [2]. According to reports from the World Health Organization, more than $80 \%$ of world's populations depend on traditional medicine for their primary health care needs [3] [4] [5]. Plants have a long history of being used in the treatment of cancer, and it is noteworthy that over $60 \%$ of currently used anti-cancer agents come from natural sources [6] [7] [8] [9] [10].

Cancer prevention approaches prescribe natural/synthetic agent(s) with the aim to delay or disrupt the pathways and processes involved at multiple steps, such as the initiation, promotion, and progression of cancer [11]. Even our fresh fruits and vegetables are being depleted of essential minerals and vitamins, often necessitating supplementation [12]. Stress hormones such as adrenaline and cortisol suppress natural killer cell function [13] [14]. More people are living in large cities with its associated pollution, stress and poor eating habits. A partial solution may be that individuals need to make critical lifestyle changes if they want to live long, healthy lives. Nutritional supplements are being increasingly recognized as an essential part of a healthy lifestyle.

The beneficial effects of curcumin on cancer, cardiovascular disease, metabolic disorders, antioxidant capacity, inflammation, and neurological, liver and respiratory disorders have recently been reviewed [15]-[21]. This is in spite of the poor bioavailability of curcumin [22] [23]. Genistein [24], resveratrol [25] [26], artemisinin [27], and vitamin C [28] also have similar clinical importance but also suffer from low bioavailability.

This study presents importance of supplements using plant derived or synthesized, chemically pure compounds that show direct toxicity to the K562 cancer cells. These supplements include curcumin, genistein, resveratrol, artemisinin, and vitamin C. Furthermore, the greatly increased cytotoxicity of micelleencapsulated curcumin and vitamin C will be compared to their free forms [29] [30] [31] [32] [33].

\section{Materials and Methods}

Cell Line and Media Production: Experiments were performed using a Chronic Myelogenous Leukemia K-652 cell line purchased from the American Type Culture Collection (ATCC).

The tissue culture media was made by adding $5 \mathrm{~mL}$ of $100 \mathrm{X}$ penicillin-streptomycin $(10,000$ units penicillin with $10 \mathrm{mg}$ of streptomycin/mL-SigmaAldrich), $5 \mathrm{~mL}$ of $200 \mathrm{mM}$ sterile-filtered L-Glutamine (Sigma-Aldrich), $5 \mathrm{~mL}$ of 
Cellgro sodium 100X bicarbonate solution (Cellgro), and $50 \mathrm{~mL}$ of fetal calf serum (Atlanta Biologics) to $500 \mathrm{~mL}$ of Minimum Essential Media, Alpha 1X, with Earle's salts without ribonucleotides, deoxyribonucleotides, and no L-glutamine (Cellgro).

Viability Stain: The viability stain used for analysis with the flow cytometer was developed by Dr. Jerry Thornthwaite. The viability stain, which uses a special medium and dye exclusion with Propidium Iodide (Sigma-Aldrich), was effective in measuring cell viability by showing a linear decrease in viability as the K562 cells were progressively subjected to a $56 \mathrm{C}$ water bath (data not shown). Also, K562 cell viability was measured directly from cell cultures in which 100 $\mu \mathrm{L}$ samples from the cell culture were added to $100 \mu \mathrm{L}$ of the viability stain. After incubation for five minutes at room temperature, the samples were suspended, incubated at room temperature for five min., and analyzed on the Accuri Flow Cytometer (BD Biosciences). Forward Light scatter was used to gate on the K562 cells and analyze the number of viable cells within the established control viability gate in the $585 \pm 20 \mathrm{~nm}$ red channel. Typical control cultures with 95\% - 99\% viability were used to establish the boundary between the live cells, essentially without staining, and dead cells, which would take up the dye and fluoresce at larger channel numbers.

Figure 1 shows the measurement of cell viability using the viability stains. The K562 cells starting culture was $1 \times 10^{5}$ cells $/ \mathrm{mL}$. The right of the vertical line was used as the cutoff of viable (left) and non-viable (right) cells, which was established for the control cultures (95\% - 97\% viable). The control, viable PI population curve came to a baseline on the left of the curve, which was the beginning of the viable cell population fluorescent staining. The dead cells were to the right of the vertical line. At Day 6, the cells were $98 \%$ viable, with up to $1.5-2.0 \times 10^{6}$ cells $/ \mathrm{mL}$. At Day 10, dead cells were detected in the positive PI fluorescence portion of the histogram. By Days 14 - 18, two distinct populations of dead cells were seen, which showed the cells where the cell membrane was compromised (peak to the left of the vertical line) and cells where the nuclear membrane was compromised (peak to the right of the vertical line). This showed the PI had intercalated into the double-stranded nucleic acids, causing a very large increase in fluorescent yield. At Day 18, all of the cells were dead. There was over a 1000 fold increase in fluorescence, which is indicative of the high fluorescence yield due to the intercalation of the $\mathrm{Pl}$ into the double stained nucleic acids.

Reagents: The highest chemical grades (97\% - 99\%) of curcumin, genistein, resveratrol, artemisinin, and vitamin $\mathrm{C}$ were used in these studies (SigmaAldrich). These reagents, except for the cell culture media soluble vitamin $\mathrm{C}$, were prepared in 100X concentrations of pure Dimethyl Sulfoxide [DMSO] (Sigma-Aldrich) and diluted by a factor of 100 in the media sufficient enough to not have DMSO only being a factor in cell viability.

Encapsulated Reagents: Curcumin and Vitamin C NutraNanoSpheres ${ }^{\mathrm{TM}}$ (NNS) were obtained from Dr. Lothar Haegele, CEO of X-labs (SwitzerlandSingapore), and had a concentration of $10.0 \%(w / v)$ or $2.5 \mathrm{mg} / 50 \mu \mathrm{L}$ for the 
curcumin and $65 \mathrm{mg} / 50 \mu \mathrm{L}$ for vitamin C.

Average Diameter Measurements of the NNS: The samples were diluted by volume in a ratio of 1:6 with DI Water and filtered by a $0.45 \mu \mathrm{m}$ Nylon membrane to remove any dust contaminants. The Zetasizer ZSP (Malvern Instruments) was used with a backscattering angle of 173 degrees to measure the particle size by dynamic light scattering. A non-negative least squares algorithm was used to generate the size distribution by intensity, which indicated the diameter of the major population for the curcumin and vitamin C NNS. The intensity data was then converted to a mass or volume distribution to compare relative amounts of each size population, which indicated the percentage of the sample represented in the respective population.

Sample Preparation and Cell Counting: In all assays, viable cell counts were obtained by mixing $100 \mu \mathrm{L}$ of a cell culture with $100 \mu \mathrm{L}$ of viability stain. All samples were analyzed within an hour after room temperature incubation for at least $5 \mathrm{~min}$. The percentage viability was stable for at least $2 \mathrm{~h}$. A $10 \mu \mathrm{L}$ portion

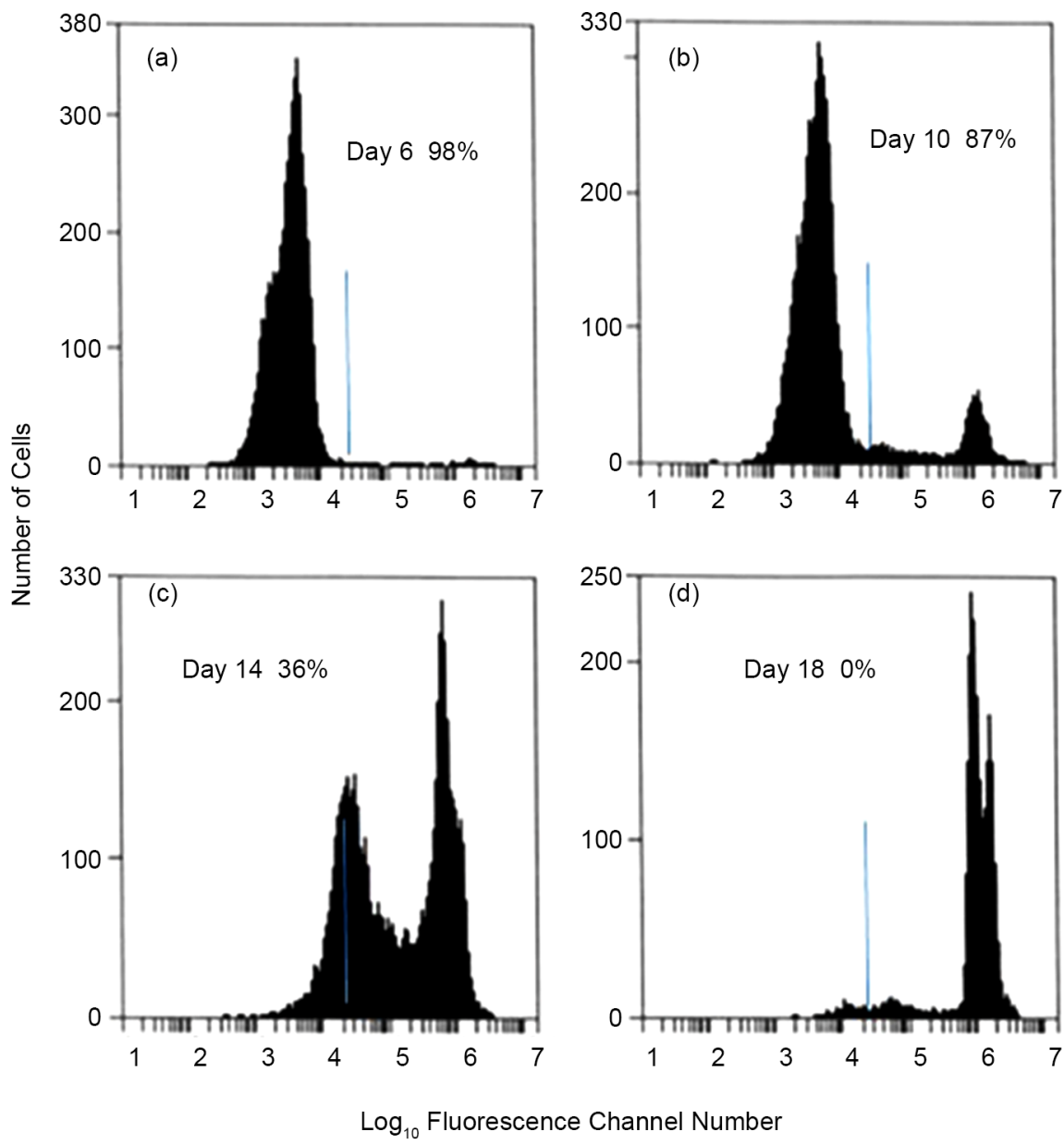

Figure 1. The effects on cell viability of K562 cancer cells vs time in culture showing increased cell death due to overcrowding and depleted nutrients. The vertical lines were used as the cutoff and to the right are the dead cells as measured by the increased uptake of the PI viability stain. The stained cell populations were gated on the light scatter cell population and analyzed in the red fluorescence channel. 
of each sample was run through the Accuri C6 Flow Cytometer at a medium flow setting. The resulting number was multiplied by 200 to determine the number of viable cells $/ \mathrm{mL}$.

Procedures for Sterilization: All reagent samples were $0.22 \mu \mathrm{m}$ sterile filtered and diluted with media in a sterile biologic safety cabinet.

Cell Growth Plate Preparation: The cells that were counted were then diluted with the media to a concentration of $1 \times 10^{5}$ viable cells $/ \mathrm{mL}$. A $500 \mu \mathrm{L}$ portion of the cells was added to each well of the 48 -well plate. The plates incubated in a Forma Scientific $\mathrm{CO}_{2}$ water-jacketed incubator at a temperature of $37.2 \mathrm{C}$ for $48 \mathrm{~h}$ to allow the cells to enter the exponential growth phase.

Addition of Compounds: After incubation for $48 \mathrm{~h}$, the stock sample compounds were diluted accordingly, by a factor of two for up to eight dilutions. A $50 \mu \mathrm{L}$ sample was added to each well, and up to six replicates of each dilution to the wells were prepared. $50 \mu \mathrm{L}$ of cell culture media was added to each control well. Once finished, every well contained $550 \mu \mathrm{L}$. The plates were typically incubated for $48 \mathrm{~h}$.

Cell Processing, Staining, and Analysis: Up to six replicates at each concentration, starting with the controls that were used to set the gates for viability, were suspended with a $500 \mu \mathrm{L}$ pipet, and $100 \mu \mathrm{L}$ portions were added to $2 \mathrm{~mL} 96$ well analysis tubes. After all of the samples were added to the tubes, $100 \mu \mathrm{L}$ of the viability stain were added using an 8-channel multipipetor, and the tray was shaken slightly and incubated for at least $5 \mathrm{~min}$. All samples were analyzed within an hour after room temperature incubation for at least $5 \mathrm{~min}$. The viability-stained cells were stable for at least $2 \mathrm{~h}$ at room temperature. A $10 \mu \mathrm{L}$ portion of each sample was run through the Accuri C6 Flow Cytometer (BD Biosciences) using the fluorescence red channel $(585 \pm 20 \mathrm{~nm})$ at a medium flow setting (200 300 cells/sec). Again the resulting number was multiplied by 200 to determine the number of viable cells $/ \mathrm{mL}$.

Percentage Cell Viability: Control cells were used to set the forward angle light scatter gate for the entire cell population gate for the cells less debris to the left of the scatter peak. The background fluorescent peak population of cells comprised the viable cells (95\% - 97\% viable). Any fluorescent cells to the right of the right baseline of the viable cell population comprised the dead cell population. The percentage viable cells were determined by dividing the number cells in the viable fluorescent cell population by the total number of viable + nonviable cells and multiplying by $100 \%$.

Data Analysis: The data collected was then graphed using PSI-Plot. The data was graphed in the form of percentage inhibition vs. concentration of each component. To calculate percentage inhibition, the values for the viable cells $/ \mathrm{mL}$ were incorporated into the equation, $\%$ Inhibition $=(1-\mathrm{X} / \mathrm{Y}) * 100 \%$, where $\mathrm{X}$ was equal to the cells $/ \mathrm{mL}$ in a particular well, and $\mathrm{Y}$ was the average number of cells $/ \mathrm{mL}$ in the control. The mean of multiple replicates (4-6) \pm the Standard Deviation (SD) were then determined. $\mathrm{LD}_{50}$ is the concentration, either in nmol or $\mu \mathrm{mol}$ per well, of the supplement of interest that causes $50 \%$ cell death. 


\section{Results}

Cytotoxicity of "Free" Supplements: Curcumin, Genistein, Resveratrol, Artemisinin and Vitamin $\mathrm{C}$.

Figure 2(a) shows percentage of inhibition of cell growth when $\mu \mathrm{mol}$ additions of either genistein or artemisinin were added to the cell culture wells. The

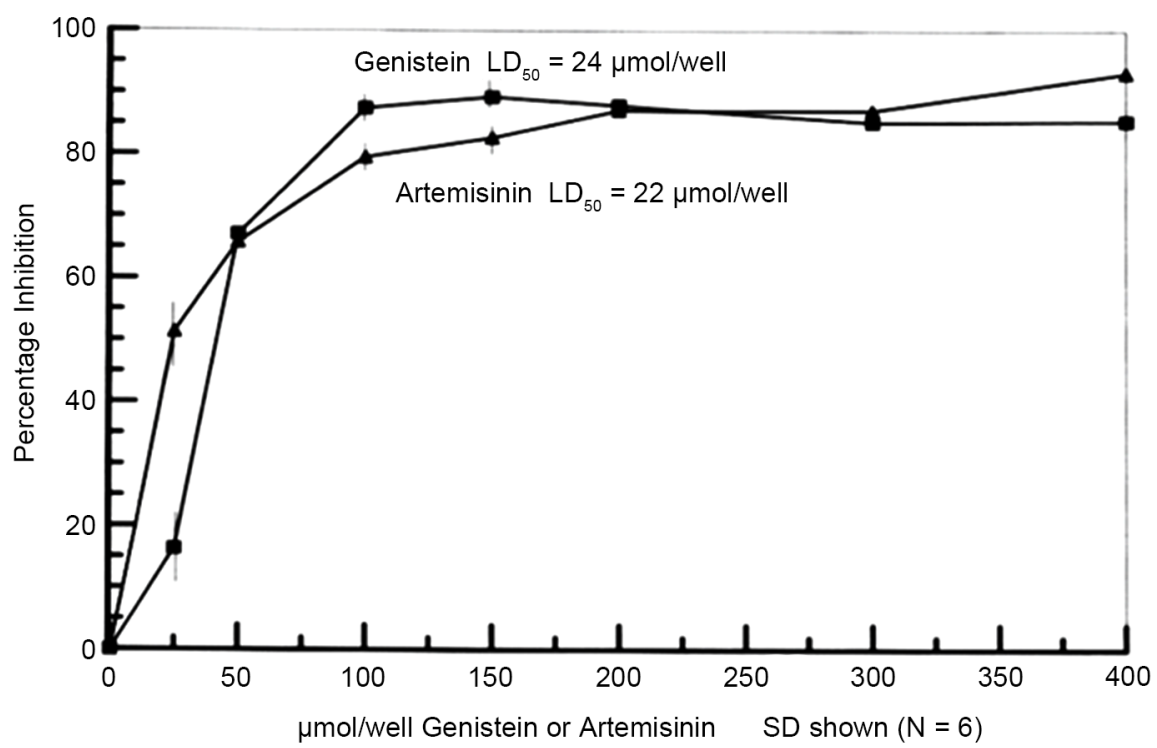

(a)

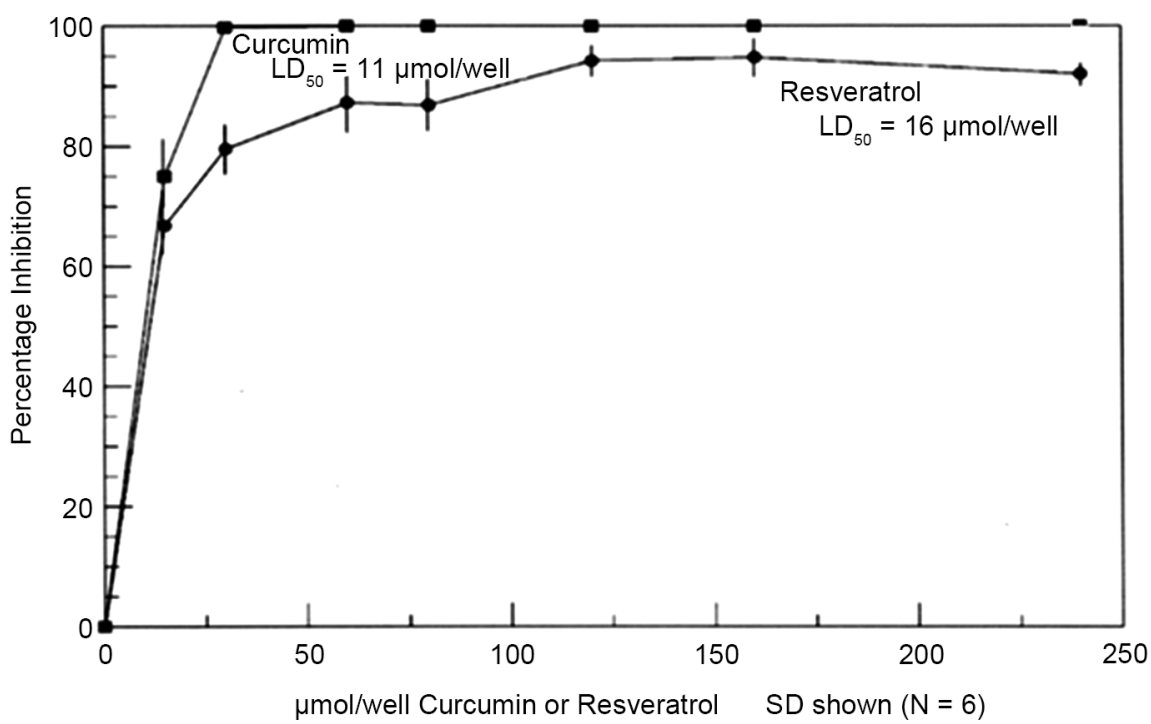

(b)

Figure 2. (a) The percentage inhibition of the growth of K562 cells in the presence of Genistein or Artemisinin from 0 to $400 \mu \mathrm{mol} / 500 \mu \mathrm{L}$ after $48 \mathrm{~h}$. The lethal dosages that kill half of the K562 cells $\left(\mathrm{LD}_{50}\right)$ are shown. SD bars $(\mathrm{n}=6)$ are shown. The mean $\mathrm{LD}_{50} \pm \mathrm{SD}$ $\mu \mathrm{mol} /$ well for eight experiments were $24.1 \pm 4.6 \mathrm{SD}$ for Genistein and $22.3 \pm 5.8$ for Artemisinin. (b) The percentage inhibition of the growth of K562 cells in the presence of Curcumin or Resveratrol from 0 to $250 \mu \mathrm{mol} /$ well after $48 \mathrm{~h}$ exposure. The lethal dosages that kill half of the K562 cells $\left(\mathrm{LD}_{50}\right)$ are shown. SD bars are shown $(\mathrm{n}=6)$. The mean $\mathrm{LD}_{50} \pm \mathrm{SD} \mu \mathrm{mol} /$ well for eight experiments were 10.9 $\pm 2.6 \mathrm{SD}$ for Curcumin and $15.9 \pm$ 6.7 SD for Resveratrol. 
lethal dosages in eight experiments, where the supplements kill $50 \%$ of the cancer cells $\left(\mathrm{LD}_{50}\right)$, for genistein was $24.1 \mu \mathrm{mol} /$ well $\pm 4.6 \mathrm{SD}$, while the $\mathrm{LD}_{50}$ for artemisinin was $22.3 \mu \mathrm{mol} /$ well $\pm 5.8 \mathrm{SD}$. In Figure $2(\mathrm{~b})$, the $\mathrm{LD}_{50}=15.9 \mu \mathrm{mol} /$ well $\pm 6.7 \mathrm{SD}$ for resveratrol and $10.9 \mu \mathrm{mol} /$ well $\pm 2.6 \mathrm{SD}$ for curcumin.

Two antioxidant compounds showed no inhibition of tumor growth. $\mathrm{N}$-acetyl Cysteine up to $400 \mu \mathrm{mol}$ (not shown) and vitamin C up to $10,000 \mu \mathrm{mol}$ (not shown), were not cytotoxic against the K562 cancer cells.

The Greatly Enhanced Anticancer Effects of Encapsulating Curcumin and Vitamin $C$ in the NutraNanoSpheres ${ }^{\mathrm{TM}}$ (NNS). The curcumin and vitamin C NNS had a concentration $2.5 \mathrm{mg} / 50 \mu \mathrm{L}$ for the curcumin and $65 \mathrm{mg} / 50 \mu \mathrm{L}$ for vitamin C. Measurements of their respective $\mathrm{LD}_{50}$ determinations showed a greatly enhanced potent activity when these compounds were encapsulated in the liposomal structure.

Figure 3 shows the size distributions for the curcumin and vitamin C NNS samples, respectively. The samples were diluted by volume in a ratio of 1:6 with DI Water and filtered by a $0.45 \mu \mathrm{m}$ Nylon membrane to remove any dust contaminants. These samples were run on the Malvern Zetasizer ZSP with a backscattering angle of 173 degrees to measure the particle size by dynamic light
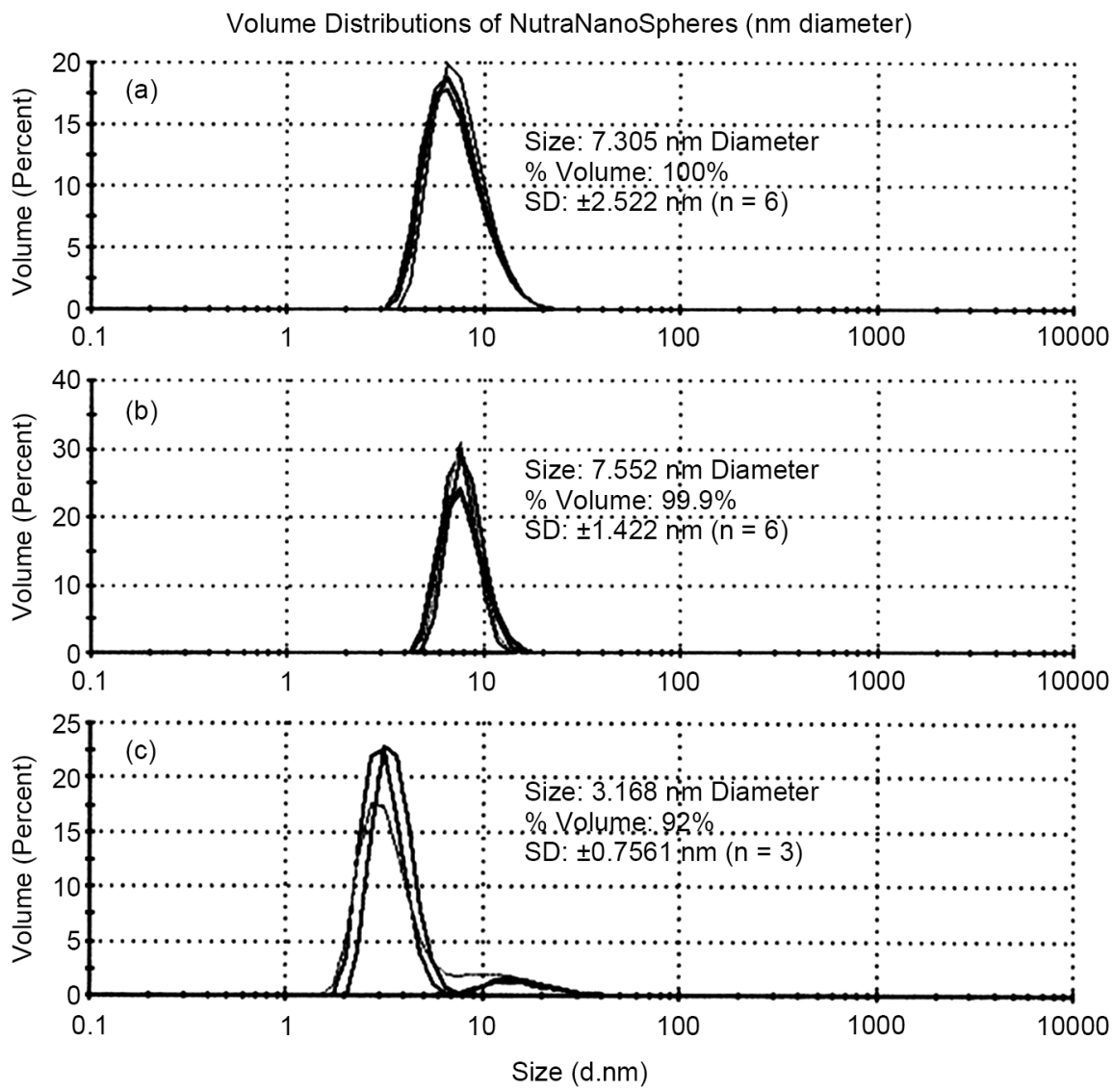

Figure 3. Volume distribution of the NutraNanoSpheres ${ }^{\mathrm{TM}}$ using the Zetasizer ZSP (Malvern Instruments) to measure the sphere sizes in $\mathrm{nm}$ diameter. Samples were run as six replicates. Standard deviation (SD) and mean diameters are shown. (a), (b) Representative Curcumin and (c) Vitamin C size distributions are shown. 
scattering. A non-negative least squares algorithm was used to generate the size distribution by intensity. Figure 3(a), Figure 3(b) reveals the diameter measurements $(7.552 \pm 7.303 \mathrm{SD} \mathrm{nm})$ for the curcumin NNS for two separate preparations, while the mean diameter for a typical preparation for NNS vitamin $\mathrm{C}$ is $3.168 \mathrm{~nm}$ is shown in Figure 3(c).

The vitamin C NNS $(3.2 \mathrm{~nm}$ diameter $-65 \mathrm{mg} / 50 \mu \mathrm{L})$ showed a mean $\mathrm{LD}_{50}=$ $133 \mu \mathrm{mol} /$ well $\pm 11 \mathrm{SD}(\mathrm{n}=4)$ was greater than 75 times more potent than the free vitamin $\mathrm{C}$, which showed no inhibition of K562 cell viability to at least $10^{4}$ $\mathrm{nm} /$ well. This can be seen in Figure 4(a), Figure 4(b) where two typical Percentage Inhibition vitamin C NNS curves are shown.

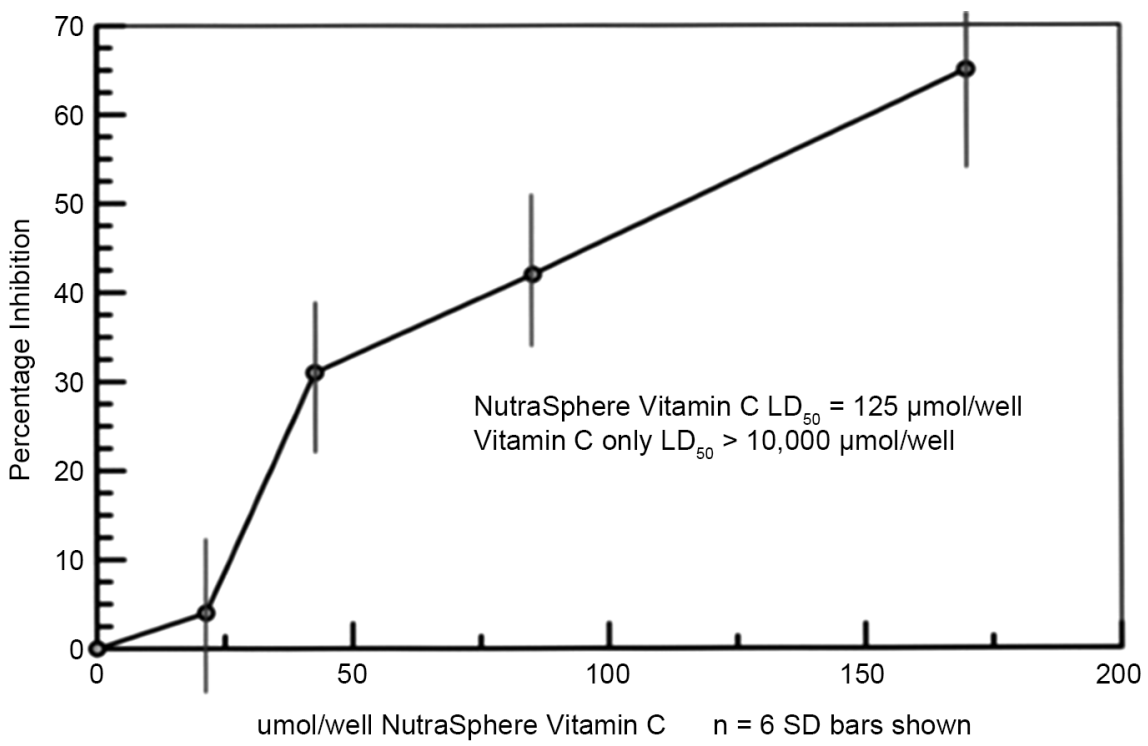

(a)

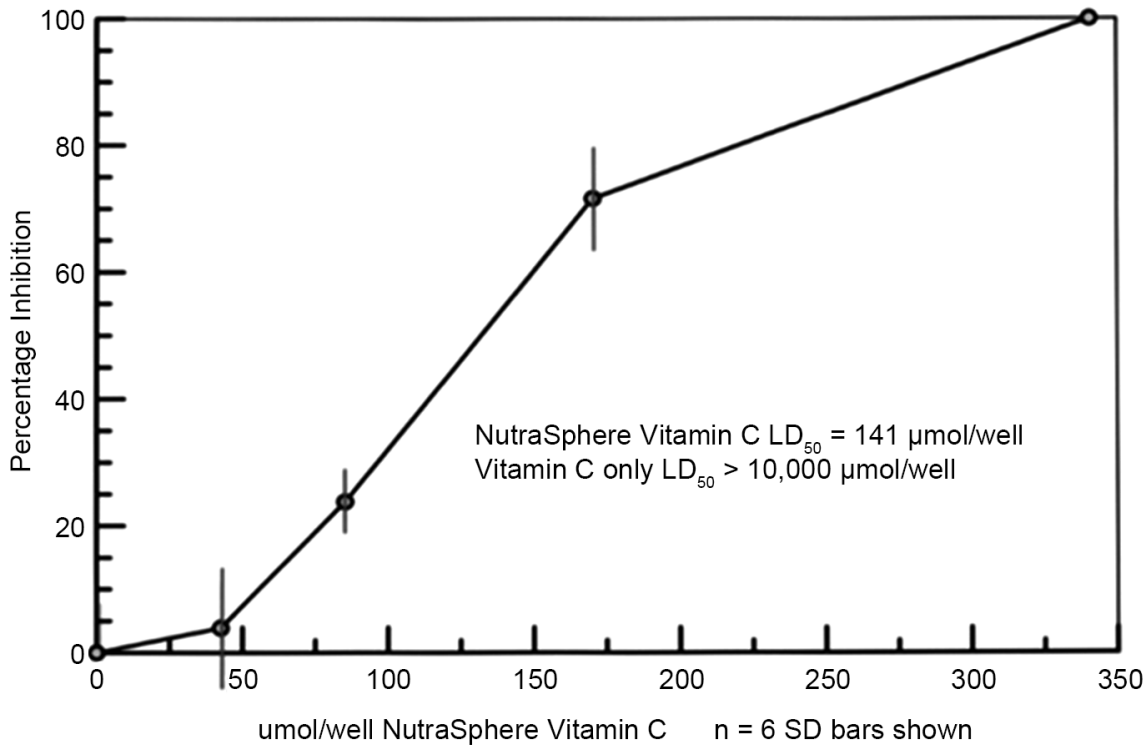

(b)

Figure 4. The percentage Inhibition of the growth of K562 cells in the presence of NutraNanoSphere ${ }^{\mathrm{TM}}$ Vitamin C from (a) 0 to 200 and (b) 0 to $350 \mu \mathrm{mol} /$ well. The $\mathrm{LD}_{50}=125$ and $141 \mu \mathrm{mol} /$ well levels example data are shown. 
The curcumin NNS $(7 \mathrm{~nm}$ diameter $-25 \mathrm{mg} / 50 \mu \mathrm{L})$ resulted in a mean $\mathrm{LD}_{50}=$ $41.3 \mathrm{nmol} /$ well $\pm 5.6 \mathrm{SD}(\mathrm{n}=8)$. Two representative percentage inhibition experiments are shown in Figure 5. In Figure $1(\mathrm{~b})$ the average $\mathrm{LD}_{50}$ for the free curcumin was $10,900 \mathrm{~nm} / \mathrm{mL}$, while the NNS curcumin averaged $\mathrm{LD}_{50}$ was 41.3 $\mathrm{nmol} /$ well. The ratio of the $\mathrm{LD}_{50}$ values $(10,900 / 41.3)$ revealed there was a 264fold increase in toxicity when the curcumin was encapsulated.

In Figure 6, cancer cell death by alteration of the cell membranes could be seen within $30 \mathrm{~s}$ of exposure to the NNS curcumin. The free curcumin showed a similar rapid killing (not shown). The killing process was probably near instantaneous, since the time from the addition of the viability stain and analyzing on the flow cytometer was about $30 \mathrm{~s}$.

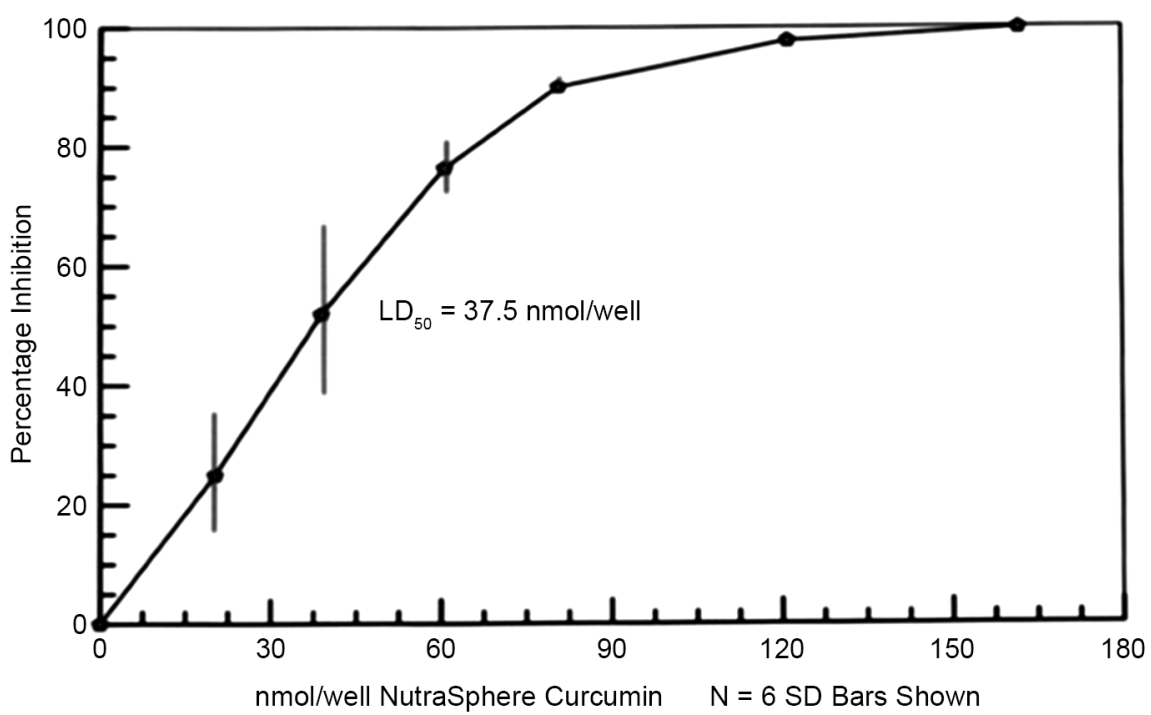

(a)

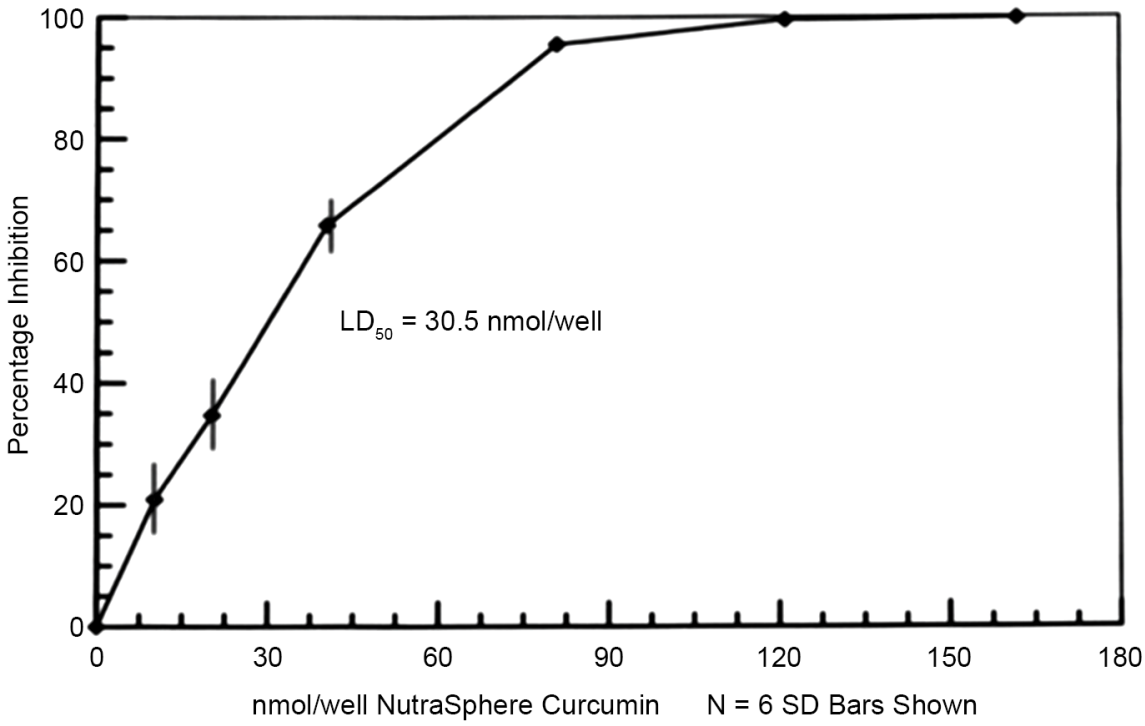

(b)

Figure 5. The percentage Inhibition of the growth of K562 cells in the presence of NutraNanoSphere ${ }^{\mathrm{TM}}$ Curcumin from 0 to $180 \mu \mathrm{mol} /$ well. The $\mathrm{LD}_{50}=37.5$ and $30.5 \mathrm{nmol} /$ well levels example data are shown. 


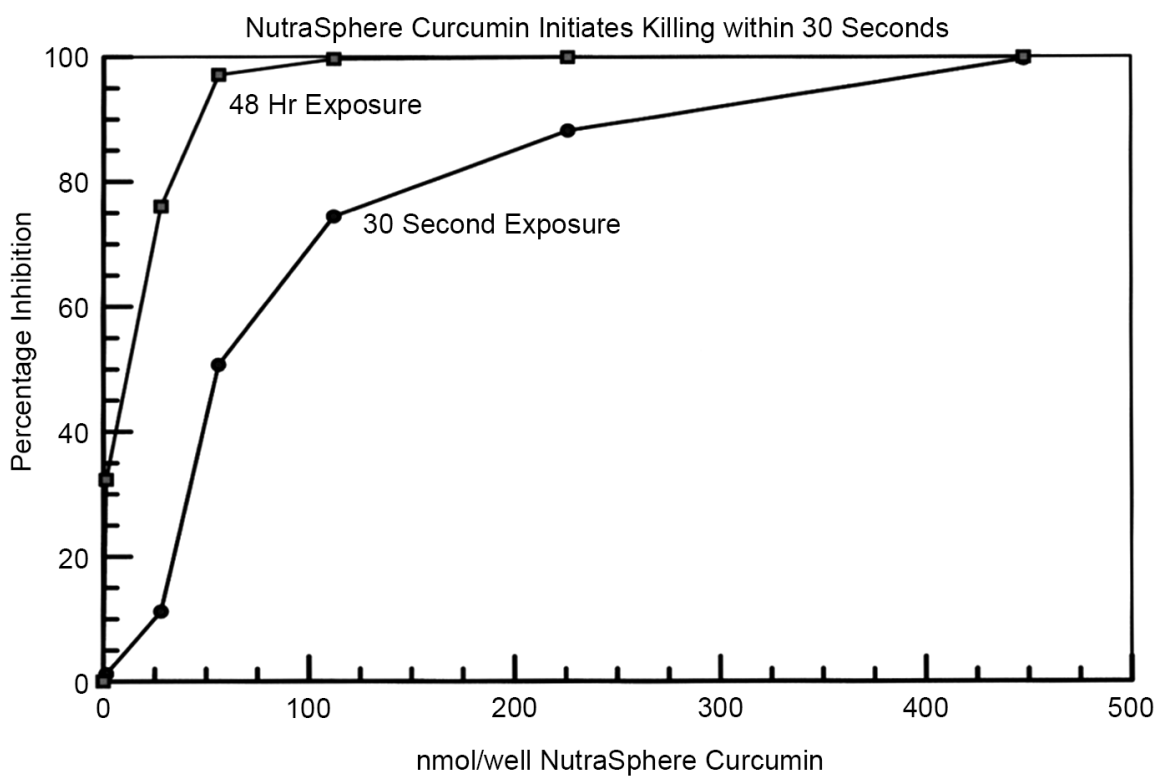

Figure 6. The percentage inhibition of the growth of K562 Cells in the presence of NutraNanoSphere ${ }^{\mathrm{TM}}$ Curcumin from 0 to $450 \mathrm{nmol} /$ well. The $\mathrm{LD}_{50}$ values per well were 20 nmol after a $48 \mathrm{hr}$ exposure and $50 \mathrm{nmol}$ for a $30 \mathrm{sec}$ exposure. The viability of the K562 cancer cells dramatically diminishes as early as 30 seconds of exposure to the NutraNanoSphere ${ }^{\mathrm{TM}}$ Curcumin.

\section{Discussion}

The ability to inhibit the viability of the K562 cancer cells was greatly enhanced by the fatty acid micelle encapsulation of curcumin and vitamin $\mathrm{C}$ in the form of NutraNanoSpheres ${ }^{\mathrm{TM}}$ (NNS). The clinical goal is to develop water-soluble mixtures of NNS with their high bioavailability (>90\%) and without degradation in the stomach and intestines for the prevention and treatment of cancer.

In the case of vitamin $C$, no inhibition of cancer cell growth was seen with the "free" vitamin C up to $1 \times 10^{4} \mu \mathrm{mol} /$ well. The solubility of vitamin C is $1 \mathrm{~g} / 3 \mathrm{~mL}$ of water or $1.89 \mathrm{M}$ [34] [35]. However, there was concern that going much above $1 \times 10^{4} \mu \mathrm{mol} /$ well would cause osmotic toxicity to the K562 cells. The encapsulated NNS vitamin C allows for the measurement of vitamin $\mathrm{C}$ toxicity against the $\mathrm{K} 562$ cells at a $\mathrm{LD}_{50}=133 \mathrm{nmol} /$ well average, which makes the anti-cancer toxic measurements even possible.

The $\mathrm{LD}_{50}$ of curcumin in the "free" form was 10,900 nmol/well (Figure 2(b)) compared to the curcumin NNS (Figure 5), which was averaged only 41.3 $\mathrm{nmol} /$ well. The $\mathrm{LD}_{50}=41.3 \mathrm{nmol} /$ well is equal to $41.3 \mathrm{nmol} / 550 \mu \mathrm{L}$ well volume, which in turn is $75.1 \mu \mathrm{M}$. The average $70 \mathrm{~kg}$ human has about 4.7 liters of blood [36]. In order to have an equivalent $\mathrm{LD}_{50}=75.1 \mu \mathrm{M}$ in $4.7 \mathrm{~L}$ of blood, one would need at least $353 \mu \mathrm{mol}$ of curcumin. The NNS contain $65 \mathrm{mg}$ of curcumin per drop $(50 \mu \mathrm{L})$ or $65 \mathrm{mg} / 0.36838 \mathrm{mg} / \mathrm{mol}=176.4 \mu \mathrm{mol}$. Therefore, to provide an $\mathrm{LD}_{50}$ would require $(353 \mu \mathrm{mol} / 176.4 \mu \mathrm{mol})=2.0$ drops of the curcumin NNS assuming $100 \%$ bioavailability, which is not too far from the $90.2 \%$ that appears in the serum within $30 \mathrm{~min}$. in patients orally ingesting the encapsulated curcu- 
min as reported by $\mathrm{X}$-Labs.

The free and NNS curcumin showed complete cell destruction (zero viable cells out of $7 \times 10^{5}$ viable cells in the control wells) at the $\mathrm{LD}_{50}=90-120$ $\mu \mathrm{mol} /$ well as early as $20 \mathrm{~h}$ in culture. Cell death by alteration of the cell membranes could be seen within $30 \mathrm{~s}$ of exposure to curcumin (Figure 6). The other components required at least $48 \mathrm{~h}$ for maximum killing, suggesting a more metabolic and/or apoptotic route of destruction using the other free supplements.

The freeform vitamin $\mathrm{C}$ did not affect the K562 cell viability. However, the NNS-vitamin C exhibited a greatly enhanced cytotoxicity against cancer cells. The same was seen for the NNS-curcumin. High dose NNS-curcumin above 1 $2 \mathrm{~mL}$ per day may be very effective in treating advanced cancers, and warrant clinical trials, because of its relatively low cytotoxicity to normal cells.

Genistein, resveratrol, and artemisinin may also be encapsulated in the NNS and be used to produce a "cocktail" of components that would show synergism or additive effects with different mechanisms of action, which include metabolic, apoptotic, and direct cytotoxicity for the prevention and treatment of cancer. These supplements may also show a significant increase in their anti-cancer activity, as seen with NNS curcumin and vitamin C.

\section{Conclusions}

In conclusion, these supplements are safe and effective in combination, especially in the NNS form, to provide a simple, water-soluble droplet formulation, which could be added to water or juice and taken on a daily basis. The high bioavailability that results from encapsulation would assure effective dosages to be determined in clinical trials for both the prevention and treatment of cancer.

The NNS Vitamin C and Curcumin presented in this paper have functions that affect virtually every aspect of cellular development. For example, vitamin $C$ has been shown to be a cofactor for methylcytosine dioxygenases, which are enzymes for DNA demethylation, an important crossroad in epigenetic regulation [37] [38]. Curcumin is a complementary therapy that may be helpful for the treatment of a variety of diseases because of its anti-inflammatory, antiangiogenic, antioxidant, and antiproliferative effects [39] [40] [41].

Our next goal is to encapsulate the other free supplements that show anticancer activity, such as genistein, resveratrol, and artemisinin. Therefore, the possibility of being able to use a combination of NNS supplement types for cancer preventative and treatment protocols will revolutionize our options in treating cancer. The advantages of using this proposed NNS cancer formulation include safety, efficacy without immunosuppression and actual facilitation of stimulation of the Natural Killer Cell activity [42] using curcumin [43] [44], genistein [45], resveratrol [46] [47] [48] [49] and at least a general immune stimulatory role with artemisinin and its derivatives [50] [51]. By simply adding NNS supplement drops together in a cancer prevention or treatment protocol in a drinkable form, would eliminate individuals having to swallow pills and greatly enhance bioavailability. 


\section{Acknowledgements}

All work was done at the Cancer Research Institute of West Tennessee, under the direction of Dr. Jerry Thornthwaite, Ph.D., who provided all of the materials and equipment used. This research was supported in part by generous donations from Mr. Henry Respess, The Shumard Foundation and the Carter Family Trust. We thank Dr. Carrie Schindler for the Malvern ZetasizerNano System analyses of the sizing of the NutraNanoSpheres. We thank Dr. Tony Kirk, Jacob Robertson, Edra Shalla, Mark Scott, Patrick Bolton, and Bonita Thornthwaite for reviewing this manuscript. We thank Special thanks goes to Dr. Lothar Haegele of $\mathrm{X}$-Labs (Singapore) for supplying the curcumin and vitamin C NutraNanoSpheres $^{\text {tix }}$ preparations for this study.

\section{References}

[1] American Cancer Society (2016) Cancer Facts \& Figures 2016. Atlanta: American Cancer Society.

[2] Aggarwal, B.B., Danda, D., Gupta, S. and Gehlot, P. (2009) Models for Prevention and Treatment of Cancer: Problems vs Promises. Biochemical Pharmacology, 78, 1083-1094. https://doi.org/10.1016/j.bcp.2009.05.027

[3] Farnsworth, N.R. (1994) Ethnobotany and the Search for New Drugs. Wiley Willett WC. Diet and health: What Should We Eat. Science, 264, 532-537. https://doi.org/10.1126/science.8160011

[4] Duraipandiyan, V., Ayyanar, M. and Ignacimuthu, S. (2006) Antimicrobial Activity of Some Ethnomedicinal Plants Used by Paliyar Tribe from Tamil Nadu, India. BMC Complementary and Alternative Medicine, 6, 35-41. https://doi.org/10.1186/1472-6882-6-35

[5] Martínez, M.E., Jacobs, E.T., Baron, J.A., Marshall, J.R. and Byers, T. (2012) Dietary Supplements and Cancer Prevention: Balancing Potential Benefits against Proven Harms. JNCI Journal of the National Cancer Institute, 104, 732-739. https://doi.org/10.1093/jnci/djs195

[6] Cragg, G.M., Kingston, D.G.I. and Newman, D.J. (2005) Anticancer Agents from Natural Products. Taylor \& Francis Group, Boca Raton, FL. Brunner-Routledge Psychology Press.

[7] Gullett, N.P., et al. (2010) Cancer Prevention with Natural Compounds. Seminars in Oncology, 3, 258-281. https://doi.org/10.1053/j.seminoncol.2010.06.014

[8] Zirpoli, G.R., et al. (2013) Supplement Use during an Intergroup Clinical Trial for Breast Cancer (S0221). Breast Cancer Research and Treatment, 137, 903-913. https://doi.org/10.1007/s10549-012-2400-2

[9] Mandair, D., Rossi, R.E., Pericleous, M., Whyand, T. and Caplin, M.E. (2014) Prostate Cancer and the Influence of Dietary Factors and Supplements: A Systematic Review. Nutrition \& Metabolism, 11, 30. https://doi.org/10.1186/1743-7075-11-30

[10] Du, J., Cullen, J.J. and Buettner, G.R. (2012) Ascorbic Acid: Chemistry, Biology and the Treatment of Cancer. Biochimica et Biophysica Acta, 1826, 443-457. https://doi.org/10.1016/j.bbcan.2012.06.003

[11] Maru, G.B., Hudlikar, R.R., Kumar, G., Gandhi, K. and Mahimkar, M.B. (2016) Understanding the Molecular Mechanisms of Cancer Prevention by Dietary Phytochemicals: From Experimental Models to Clinical Trials. World Journal of Biological Chemistry, 7, 88-99. https://doi.org/10.4331/wjbc.v7.i1.88 
[12] Scheer, R. and Moss, D. (2011) Dirt Poor: Have Fruits and Vegetables Become Less Nutritious? Scientific American.

[13] Reiche, E.M., Nunes, S.O. and Morimoto, H.K. (2004) Stress, Depression, the Immune System, and Cancer. Lancet Oncology, 5, 617-625. https://doi.org/10.1016/S1470-2045(04)01597-9

[14] Pulido-Moran, M., Moreno-Fernandez, J., Ramirez-Tortosa, C. and Ramirez-Tortosa, M. (2016) Curcumin and Health. Molecules, 21, 264. https://doi.org/10.3390/molecules21030264

[15] Rein, M.J., et al. (2013) Bioavailability of Bioactive Food Compounds: A Challenging Journey to Bioefficacy. British Journal of Clinical Pharmacology, 75, 588-602.

[16] Verma, V. (2016) Relationship and Interactions of Curcumin with Radiation Therapy. World Journal of Clinical Oncology, 7, 275-283. https://doi.org/10.5306/wjco.v7.i3.275

[17] Shindikar, A., Singh, A., Nobre, M. and Kirolikar, S. (2016) Curcumin and Resveratrol as Promising Natural Remedies with Nanomedicine Approach for the Effective Treatment of Triple Negative Breast Cancer. Journal of Oncology, 2016, Article ID: 9750785. https://doi.org/10.1155/2016/9750785

[18] Ruiz de Porras, V., et al. (2016) Curcumin Mediates Oxaliplatin-Acquired Resistance Reversion in Colorectal Cancer Cell Lines through Modulation of CXCChemokine/NF-кB Signalling Pathway. Scientific Reports, 6, 24675. https://doi.org/10.1038/srep24675

[19] Yallapu, M.M., Jaggi, M. and Chauhan, S.C. (2013) Curcumin Nanomedicine: A Road to Cancer Therapeutics. Current Pharmaceutical Design, 19, 1994-2010. https://doi.org/10.2174/1381612811319110004

[20] Terlikowska, K.M., Witkowska, A.M., Zujko, M.E., Dobrzycka, B. and Terlikowski, S.J. (2014) Potential Application of Curcumin and Its Analogues in the Treatment Strategy of Patients with Primary Epithelial Ovarian Cancer. International Journal of Molecular Sciences, 15, 21703-21722. https://doi.org/10.3390/ijms151221703

[21] Rocks, N., et al. (2012) Curcumin-Cyclodextrin Complexes Potentiate Gemcitabine Effects in an Orthotopic Mouse Model of Lung Cancer. British Journal of Cancer, 107, 1083-1092. https://doi.org/10.1038/bjc.2012.379

[22] Shen, L., Liu, C.C., An, C.Y. and Ji, H.F. (2016) How Does Curcumin Work with Poor Bioavailability? Clues from Experimental and Theoretical Studies. Scientific Reports, 6, 20872. https://doi.org/10.1038/srep20872

[23] Choudhury, S.T., et al. (2016) Vesicular (Liposomal and Nanoparticulated) Delivery of Curcumin: A Comparative Study on Carbon Tetrachloride-Mediated Oxidative Hepatocellular Damage in Rat Model. International Journal of Nanomedicine, 11, 2179-2193.

[24] Tang, J., et al. (2011) Eudragit Nanoparticles Containing Genistein: Formulation, Development, and Bioavailability Assessment. International Journal of Nanomedicine, 6, 2429-2235.

[25] Neves, A.R., Martins, S., Segundo, M.A. and Reis, S. (2016) Nanoscale Delivery of Resveratrol towards the Enhancement of Supplements and Nutraceuticals. $\mathrm{Nu}$ trients, 8, 131. https://doi.org/10.3390/nu8030131

[26] Stockwin, L.H., et al. (2009) Artemisinin Dimer Anti-Cancer Activity Correlates with Heme-Catalyzed ROS Generation and ER Stress Induction. International Journal of Cancer, 125, 1266-1275. https://doi.org/10.1002/ijc.24496

[27] Ferreira, J.F., Luthria, D.L., Sasaki, T. and Heyerick, A. (2010) Flavonoids from Artemisia annua L. as Antioxidants and Their Potential Synergism with Artemisinin 
against Malaria and Cancer. Molecules, 15, 3135-3170.

https://doi.org/10.3390/molecules15053135

[28] Parrow, N.L., Leshin, J.A. and Levine, M. (2013) Parenteral Ascorbate as a Cancer Therapeutic: A Reassessment Based on Pharmacokinetics. Antioxidants \& Redox Signaling, 17, 2141-2156. https://doi.org/10.1089/ars.2013.5372

[29] Marrink, S.J., Tieleman, D.P. and Mark, A.E. (2000) Molecular Dynamics Simulation of the Kinetics of Spontaneous Micelle Formation. The Journal of Physical Chemistry B, 104, 12165-12173. https://doi.org/10.1021/jp001898h

[30] Tieleman, D.P., van der Spoel, D. and Berendsen, H.J.C. (2000) Molecular Dynamics Simulations of Dodecylphosphocholine Micelles at Three Different Aggregate Sizes: Micellar Structure and Chain Relaxation. The Journal of Physical Chemistry $B$, 104, 6380-6388. https://doi.org/10.1021/jp001268f

[31] Yerragunta, B., Jogala, S., Chinnala, K.M. and Aukunuru, J. (2015) Development of a Novel 3-Month Drug Releasing Risperidone Microspheres. Journal of Pharmacy and Bioallied Sciences, 7, 37-44. https://doi.org/10.4103/0975-7406.148777

[32] Dhule, S.S., et al. (2014) The Combined Effect of Encapsulating Curcumin and C6 Ceramide in Liposomal Nanoparticles against Osteosarcoma. Molecular Pharmaceutics, 11, 417-427. https://doi.org/10.1021/mp400366r

[33] Bozzuto, G. and Molinari, A. (2015) Liposomes as Nanomedical Devices. International Journal of Nanomedicine, 10, 975-999. https://doi.org/10.2147/IJN.S68861

[34] Altamirando, C., Neto, R., Pires, R.F., Malagoni, R.A. and Franco Jr., M.R. (2010) Solubility of Vitamin C in Water, Ethanol, Propan-1-ol, Water + Ethanol, and Water + Propan-1-ol at 298.15 and 308.15 K. Journal of Chemical \& Engineering Data, 55, 1718-1721. https://doi.org/10.1021/je900687y

[35] Chase, D., et al. (1970) Remington's Pharmaceutical Sciences. 14th Edition, Mack Pub Co., Easton, 1036

[36] World Book Rush-Presbyterian-St. Luke's Medical Center Medical Encyclopedia (1995) 7th Edition, World Book, Chicago, 120-121.

[37] Camarena, V. and Wang, G. (2016) The Epigenetic Role of Vitamin C in Health and Disease. Cellular and Molecular Life Sciences, 8, 1645-1658. https://doi.org/10.1007/s00018-016-2145-x

[38] Young, J.I., Züchner, S. and Wang, G. (2015) Regulation of the Epigenome by Vitamin C. Annual Review of Nutrition, 35, 545-564. https://doi.org/10.1146/annurev-nutr-071714-034228

[39] Antiga, E., Bonciolini, V., Volpi, W., Del Bianco, E. and Caproni, M. (2015) Oral Curcumin (Meriva) Is Effective as an Adjuvant Treatment and Is Able to Reduce IL-22 Serum Levels in Patients with Psoriasis Vulgaris. BioMed Research International, 28, 1-7. https://doi.org/10.1155/2015/283634

[40] Zaman, M.S., et al. (2016) Curcumin Nanoformulation for Cervical Cancer Treatment. Scientific Reports, 6, 20051. https://doi.org/10.1038/srep20051

[41] Jingling, T., et al. (2011) Eudragit Nanoparticles Containing Genistein: Formulation, Development, and Bioavailability Assessment. International Journal of Nanomedicine, 6, 2429-2435.

[42] Thornthwaite, J.T., Shah, H., Shah, P. and Respess, H. (2012) The Natural Killer Cell: A Historical Perspective and the Use of Supplements to Enhance NKC Activity. Journal of Immune Based Therapies, Vaccines and Antimicrobials, 1, 21-52. https://doi.org/10.4236/jibtva.2012.13004

[43] Halder, R.C., et al. (2015) Curcuminoids and $\omega$-3 Fatty Acids with Anti-Oxidants 
Potentiate Cytotoxicity of Natural Killer Cells against Pancreatic Ductal Adenocarcinoma Cells and Inhibit Interferon $\gamma$ Production. Frontiers in Physiology, 6, 129. https://doi.org/10.3389/fphys.2015.00129

[44] Xi, Y., et al. (2015) Induction of BCL2-Interacting Killer, BIK, Is Mediated for Anti-Cancer Activity of Curcumin in Human Head and Neck Squamous Cell Carcinoma Cells. Journal of Cancer, 6, 327-332. https://doi.org/10.7150/jca.11185

[45] Guo, T.L., et al. (2006) Modulation of Immune Response Following Dietary Genistein Exposure in F0 and F1 Generations of C57BL/6 Mice: Evidence of Thymic Regulation. Food and Chemical Toxicology, 44, 316-325. https://doi.org/10.1016/j.fct.2005.08.001

[46] Luis, E.J., Takami, A., Trung, L.Q. and Nakao, S. (2013) Ataxia-Telangiectasia Mutated Kinase-Mediated Upregulation of NKG2D Ligands on Leukemia Cells by Resveratrol Results in Enhanced Natural Killer Cell Susceptibility. Cancer Science, 104, 657-662. https://doi.org/10.1111/cas.12141

[47] Malhotra, A., Bath, S. and Elbarbry, F. (2015) An Organ System Approach to Explore the Antioxidative, Anti-Inflammatory, and Cytoprotective Actions of Resveratrol. Oxidative Medicine and Cellular Longevity, 2015, Article ID: 803971. https://doi.org/10.1155/2015/803971

[48] Huynh, L., Neale, C., Pomès, R. and Allen, C. (2012) Computational Approaches to the Rational Design of Nanoemulsions, Polymeric Micelles, and Dendrimers for Drug Delivery. Nanomedicine, 8, 20-36. https://doi.org/10.1016/j.nano.2011.05.006

[49] Santos, A.C., Veiga, F. and Ribeiro, A.J. (2011) New Delivery Systems to Improve the Bioavailability of Resveratrol. Expert Opinion on Drug Delivery, 8, 973-990. https://doi.org/10.1517/17425247.2011.581655

[50] Okoye, T.C., et al. (2014) Immunomodulatory Effects of Stachytarpheta cayennensis Leaf Extract and Its Synergistic Effect with Artesunate. BMC Complementary and Alternative Medicine, 14, 376. https://doi.org/10.1186/1472-6882-14-376

[51] Zhou, W., et al. (2005) A Novel Artemisinin Derivative, 3-(12- $\beta$-Artemisininoxy) Phenoxyl Succinic Acid (SM735), Mediates Immunosuppressive Effects in Vitro and in Vivo. Acta Pharmacologica Sinica, 26, 1352-1358. https://doi.org/10.1111/j.1745-7254.2005.00232.x

Submit or recommend next manuscript to SCIRP and we will provide best service for you:

Accepting pre-submission inquiries through Email, Facebook, LinkedIn, Twitter, etc. A wide selection of journals (inclusive of 9 subjects, more than 200 journals)

Providing 24-hour high-quality service

User-friendly online submission system

Fair and swift peer-review system

Efficient typesetting and proofreading procedure

Display of the result of downloads and visits, as well as the number of cited articles

Maximum dissemination of your research work

Submit your manuscript at: http://papersubmission.scirp.org/

Or contact abc@scirp.org 